\title{
The Role of the Proteasome in Platelet Function
}

\author{
Abed El-Hakim El-Kadiry ${ }^{1,2}$ and Yahye Merhi ${ }^{1,2, *}$ \\ 1 Laboratory of Thrombosis and Hemostasis, Montreal Heart Institute, Research Centre, \\ Montreal, QC H1T 1C8, Canada; abed.kadiry@gmail.com \\ 2 Biomedical Sciences Program, Faculty of Medicine, Université de Montréal, Montreal, QC H3T 1J4, Canada \\ * Correspondence: yahye.merhi@icm-mhi.org; Tel.: +1-514-376-3330
}

\section{check for}

updates

Citation: El-Kadiry, A.E.-H.; Merhi, Y. The Role of the Proteasome in Platelet Function. Int. J. Mol. Sci. 2021, 22, 3999. https://doi.org/10.3390/ ijms22083999

Academic Editor: Isabella Russo

Received: 16 March 2021

Accepted: 8 April 2021

Published: 13 April 2021

Publisher's Note: MDPI stays neutral with regard to jurisdictional claims in published maps and institutional affiliations.

Copyright: (c) 2021 by the authors. Licensee MDPI, Basel, Switzerland. This article is an open access article distributed under the terms and conditions of the Creative Commons Attribution (CC BY) license (https:/ / creativecommons.org/licenses/by/ $4.0 /)$.

\begin{abstract}
Platelets are megakaryocyte-derived acellular fragments prepped to maintain primary hemostasis and thrombosis by preserving vascular integrity. Although they lack nuclei, platelets harbor functional genomic mediators that bolster platelet activity in a signal-specific manner by performing limited de novo protein synthesis. Furthermore, despite their limited protein synthesis, platelets are equipped with multiple protein degradation mechanisms, such as the proteasome. In nucleated cells, the functions of the proteasome are well established and primarily include proteostasis among a myriad of other signaling processes. However, the role of proteasome-mediated protein degradation in platelets remains elusive. In this review article, we recapitulate the developing literature on the functions of the proteasome in platelets, discussing its emerging regulatory role in platelet viability and function and highlighting how its functional coupling with the transcription factor NF- $\mathrm{kB}$ constitutes a novel potential therapeutic target in atherothrombotic diseases.
\end{abstract}

Keywords: platelets; proteasome; NF-kB; atherothrombosis

\section{Introduction}

Platelets are anucleate blood fragments originating from maturing megakaryocytesprecursor cells derived from pluripotent hematopoietic stem cells [1,2]. With a discoid shape at rest, a dimension of $3 \mu \mathrm{m} \times 0.5 \mu \mathrm{m}$, a lifespan of 10 days, and an average count of 250 million/mL of adult blood, platelets circulate in blood vessels, patrolling vascular endothelial cell lining [3,4]. Upon vascular damage or lesion, platelets adhere to exposed subendothelial matrix components, such as collagen, fibrinogen, and von Willebrand factor (VWF), thereby undergoing activation, secretion, spreading, and aggregation-unique platelet hemostatic and thrombotic functions that culminate in the conversion of $\alpha \mathrm{Ilb} \beta 3$-bound fibrinogen to fibrin by thrombin, and the formation of a contractile fibrin-platelet plug that facilitates vascular recovery [5-7]. Besides primary hemostasis and thrombosis, the functions of platelets span inflammation, host defense, cancer, vascular tone regulation, and atherothrombotic diseases among others [8-25]. The execution of platelet function is met with a plethora of adhesive receptors (GPIb/IX/V complex, PSGL-1, GPVI immunoglobulin, $\alpha 5 \beta 1 / \alpha 2 \beta 1$ integrins), activation receptors (protein tyrosine kinases, G-protein coupled receptors, $\alpha \mathrm{Il} b \beta 3$ integrin), secreted granule reservoirs (adhesion molecules, immunologic molecules, coagulation factors, chemokines, regulators of growth and angiogenesis, protease inhibitors, digestive enzymes, platelet agonists including ADP and Thromboxane A2, and platelet primers including epinephrine and soluble CD40L (sCD40L)), and dynamic cytoskeletal proteins (actin, myosin, spectrin) [26-37]. Generally, platelets inherit their cytoplasmic and membranous molecules from megakaryocytes early during platelet formation. However, platelets can perform limited de novo protein synthesis of important hemostatic and/or thrombo-inflammatory mediators, such as IL-1 $\beta$ and COX-1, in response to specific signals $[27,38]$. Deeper investigations into the biological intricacies of genome-devoid platelets have also revealed the presence of multiple transcription factors like nuclear factor- $\mathrm{KB}$ (NF$\mathrm{kB})$, translational machinery, microRNA, and more than 2500 mRNA transcripts [39-52]. 
These genomic apparatuses were demonstrated to fulfill genomic and/or non-genomic intra-platelet and/or extra-platelet functions [53-61]. Another functional paradox is that platelets are equipped with distinct and collaborative protein degradation mechanisms even though their protein synthesis capacity is limited. Their pool of degradative machinery groups calpain, caspases, matrix metalloproteinases, surface proteases, lysosomal proteases, and the proteasome [62]. In nucleated cells, proteasomal roles are well defined and primarily include the degradation of unneeded/misfolded proteins to maintain proteostasis, the regulation of signal transduction cascades, and the modulation of transcriptional activity (e.g., NF-kB activation) [63-69]. On the other hand, the role of the proteasome in platelets is less characterized. Herein, we orderly summarize the data generated hitherto on the regulatory roles of the proteasome in platelets and their contribution to platelet viability and function. We also highlight the importance of the proteasome/NF- $\mathrm{kB}$ dyad in platelets and its relevant therapeutic targeting in atherothrombotic diseases.

\section{The Proteasome}

\subsection{Structures}

The standard proteasome is a $26 \mathrm{~S}$ multi-catalytic protease complex (2.4 MDa) comprising two $19 \mathrm{~S}$ regulatory caps $(750 \mathrm{kDa}$ each) and a central $20 \mathrm{~S}$ proteolytic subunit (around $750 \mathrm{kDa}$ ) found within the core. The $19 \mathrm{~S}$ complex is an arrangement of 2 multimers, the lid, and the base. The lid comprises up to 10 non-ATPase subunits. The base comprises 2 nonATPase subunits and 6 homologous hexamer ring-forming ATPases (PSMC2/1/4/6/3/5) and is responsible for the assembly of the $19 \mathrm{~S}$ regulatory particles with the $20 \mathrm{~S}$ core particle, allowing the formation and activation of the ATP-dependent $26 \mathrm{~S}$ proteasome. The $20 \mathrm{~S}$ core particle is composed of 28 heterogeneous subunits arranged in 4 rings: 2 beta rings on the inner side and 2 pore-forming non-catalytic alpha rings on the outer side. Each ring thus groups 7 subunits ( $\beta 1-7$ and $\alpha 1-7)$. Among the beta subunits, 3 perform caspase-, trypsin-, and chymotrypsin-like proteolytic activities ( $\beta 1$ /PSMB6, $\beta 2 /$ PSMB7, and $\beta 5 /$ PSMB5, respectively) by cleaving peptide bonds following acidic, basic, and hydrophobic amino acids, respectively. Alone, the proteolytic $20 \mathrm{~S}$ core performs ubiquitin-independent degradation. Assembled with the $19 \mathrm{~S}$ regulatory particles to form the $26 \mathrm{~S}$ proteasome, it specifically degrades ubiquitin-conjugated proteins in an ATP-dependent manner (Figure 1).

Ubiquitin is a eukaryotic sequence of 76 amino acids weighing approximately $8 \mathrm{kDa}$. Its coupling to proteins is catalyzed sequentially by the ubiquitin-activating (E1) enzyme, the ubiquitin conjugation (E2) enzyme, and the ubiquitin ligase (E3). First, in the reaction, the E1 enzyme binds and activates ubiquitin by consuming ATP. Then E2 forms an intermediate complex with activated ubiquitin. Lastly, E3 acts as a scaffold that interacts with both the E2-ubiquitin complex and the protein substrate, facilitating the transfer of ubiquitin from E2 to the substrate. An iso-peptide bond thus forms between the c-terminal glycine residue of ubiquitin and the consensus lysine residues in the substrate. Noteworthy, a specific E3 subtype called E4 ligase can further elongate linear ubiquitin chains at internal lysine residues to create several polyubiquitin chain conformations. This internal ubiquitin linkage serves as a code that determines the protein's fate. For instance, internal ubiquitin linkage at lysine 11, 29, and 48 residues is a protein tag for proteasomal degradation. Linkages at the other 4 residues (K6, K27, K33, K63) modulate protein activity, localization, or interaction/scaffolding. Along with the proteasome, ubiquitin and its enzymes form the ubiquitin-proteasome system (UPS) (Figure 1) [70-75]. 

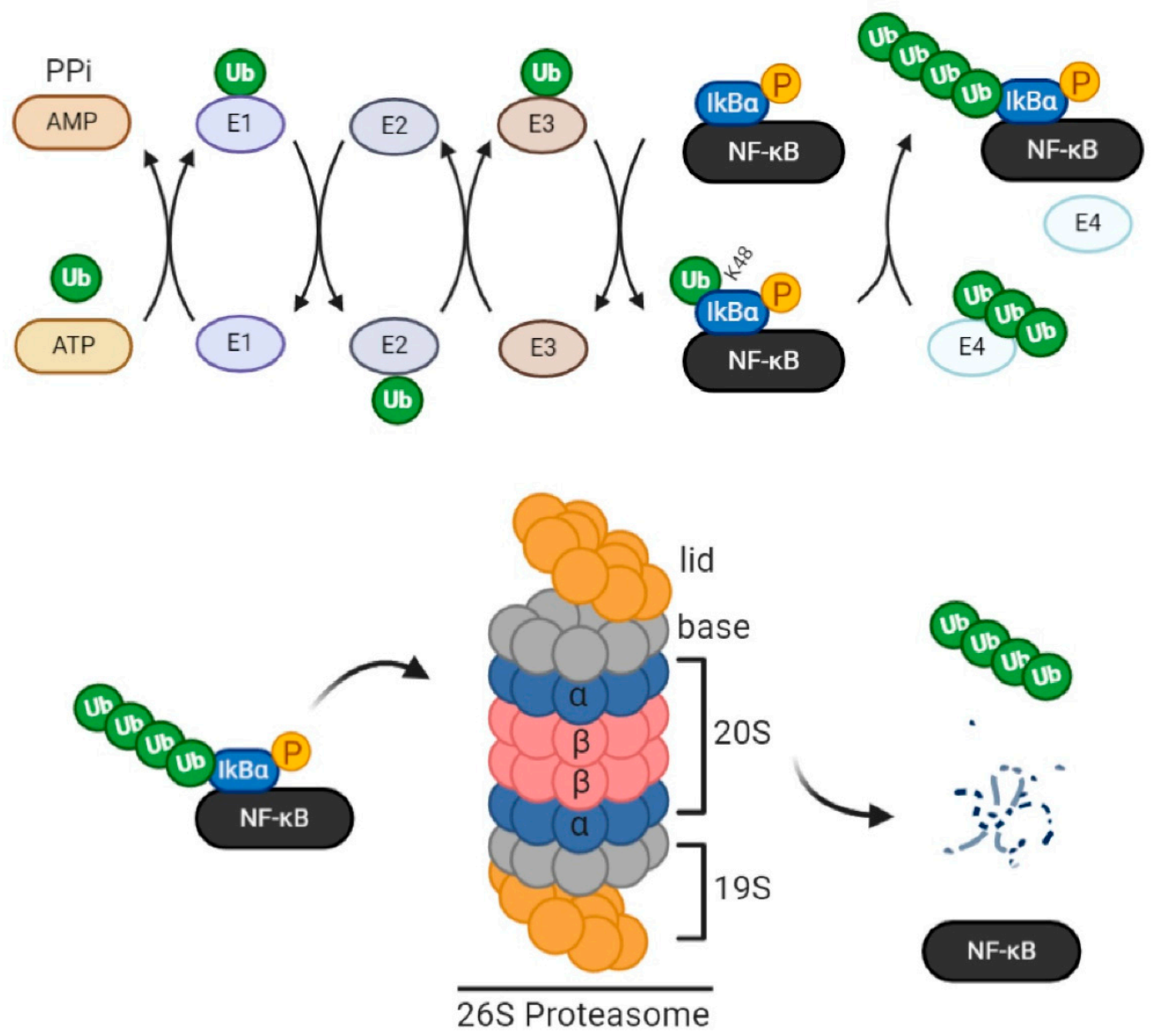

Figure 1. Components of the ubiquitin proteasome system (UPS). Protein ubiquitination is catalyzed sequentially by the ubiquitin-activating enzyme (E1), ubiquitin conjugation (E2) enzyme, and ubiquitin ligase (E3). First, the E1 enzyme binds and activates ubiquitin by consuming ATP. Then E2 forms an intermediate complex with activated ubiquitin. Lastly, E3 acts as a scaffold that interacts with both the E2-ubiquitin complex and the protein substrate, facilitating the transfer of ubiquitin from E2 to the substrate. An iso-peptide bond, thus, forms between the c-terminal glycine residue of ubiquitin and consensus lysine residues ( 7 total) of the substrate. Internal ubiquitin linkage at K11, 29, and 48 residues constitutes a tag for proteasomal trafficking. E4 ligase, a specific E3 subtype, can further elongate linear ubiquitin chains to create several polyubiquitin chain conformations. In this example, NF- $\kappa$ B is the protein substrate. Following its phosphorylation by IKK, IкB (inhibitory subunit of $\mathrm{NF}-\mathrm{kB}$ ) is polyubiquitinated for proteasomal trafficking. The standard proteasome $26 \mathrm{~S}$ groups two regulatory subunits (19S each) comprising 2 multimers each, the lid and the base, in addition to a catalytic core (20S) whose $\beta$ rings harbor caspase-, trypsin-, and chymotrypsin-like proteolytic activities ( $\beta 1, \beta 2$, and $\beta 5$, respectively). Upon substrate entry into the proteasome lid, the base facilitates the opening of the entry pore of $20 S \alpha$ rings, enabling protein translocation and degradation in the core by $\beta$ rings. Furthermore, the base, due to the chaperone-like activity of its highly specific ubiquitin receptor subunits, ensures the selectivity of degradation, as it permits the entry of ubiquitinated proteins only, by forming covalent bonds with monomeric or polymeric ubiquitin chains. The 19S subunit also contains deubiquitinating enzymes (DUBs) that facilitate protein unfolding, translocation, and degradation within the core. In the given scenario, IкB is deubiquitinated and degraded within the proteasome so that activated NF- $\mathrm{BB}$ becomes free to function.

More in-depth, during 26S proteasome formation and activation, PSMC1 facilitates the opening of the entry pore of $20 \mathrm{~S} \alpha$ subunits, enabling protein translocation and degradation in the core. Meanwhile, the base, with the chaperone-like activity of its highly specific ubiquitin receptor subunits, further ensures the selectivity of the process, permitting the entry of ubiquitinated proteins only, by forming covalent bonds with monomeric or 
polymeric ubiquitin chains. In addition to its substrate recognition, unfolding, and protein translocation properties, the $19 \mathrm{~S}$ regulatory subunit conducts deubiquitination $[63,67,76,77]$. In general, deubiquitination is carried by deubiquitinating enzymes (DUBs) and can be UPS-independent; therein, DUBs alter protein trafficking or enhance protein stability. Around 80 DUBs have been identified and grouped into 6 families based on the homology of their catalytic domain sequences. They exist either as free enzymes or are associated with large enzyme complexes, such as the proteasome. In UPS, deubiquitination is mediated by three 19S-associated DUBs (USP14, UCHL5, and Rpn11) and facilitates the unfolding, translocation, and degradation of proteins within the 20S core [78,79].

In addition to its standard form, the proteasome exists in other forms, such as the thymoproteasome (TPr), intermediate proteasomes, hybrid proteasomes, and the immunoproteasome (IP) [80,81]. For example, the IP is responsible for MHC class I-mediated antigen presentation through generating antigenic peptides. While the IP is constitutively expressed in immune cells of myeloid or lymphoid origins, it is synthesized in response to interferons or lipopolysaccharides in nucleated cells. IP assembly occurs through the substitution of proteolytic $\beta 1, \beta 2$, and $\beta 5$ subunits of the $20 \mathrm{~S}$ core with their IP counterparts: $\beta 1 \mathrm{i} / \mathrm{PSMB} 9, \beta 2 \mathrm{i} / \mathrm{PSMB} 10$, and $\beta 5 \mathrm{i} / \mathrm{PSMB} 8$. In contrast to the $26 \mathrm{~S}$ proteasome, which harbors 195 regulatory subunits, the immunoproteasome is regulated by two heptameric $11 \mathrm{~S}$ subunits, which consist of PA28 $\alpha$ /PSME1 and $\beta /$ PSME2 subunits and are induced by interferon- $\gamma[82,83]$ to facilitate substrate access into the proteasomal core $[84,85]$.

\subsection{Functions}

The functional importance of proteasome-mediated protein degradation was initially delineated through in vivo examination of UPS characteristics in pathological conditions. In neurodegenerative diseases, for instance, UPS was found to be impaired [86] with a widespread accumulation of ubiquitinated proteins [87]. In a subclass of Parkinson's disease, E3 ligase was reported to be mutated [88]. In age-related disorders, a decline in proteasomal activity and an accumulation of misfolded proteins were also recorded [89]. In humans, PSMB8 mutations cause a rare genetic disorder (chronic atypical neutrophilic dermatosis with lipodystrophy and elevated temperature, or CANDLE) that presents with accumulated ubiquitinated proteins, high levels of type I interferon, and thrombocytopenia [90].

To better assess the roles of the proteasome in cellular functions, genetic and pharmacological methodologies were approached. A study by Bedford et al. [77] showed that PSMC1 deletion in vivo is embryonically lethal, and neuronal 26S proteasome depletion leads to neurodegeneration. Disrupting the ubiquitin gene also causes neuronal death and impairs energy expenditure systems, exposing the organism to obesity [86]. The extensive use of multiple natural or synthesized proteasome inhibitors (Table 1) including epoxomicin, lactacystin, DCI, $\mathrm{HgCl}_{2}$, bortezomib (PS-341), carfilzomib, MG132, PCMB, PSI (benzyloxycarbonyl-Ile-Glu(O-tert.-butyl)-Ala-leucinal), and Mersalyl acid has ascribed to the proteasome multiple cellular roles [91-97]. Therefrom, it was found that proteasome-mediated protein degradation/processing not only removes aberrant proteins but also regulates (1) signal transduction cascades, (2) receptor turnover/desensitization, (3) enzymatic activity, (4) cell cycle progression, (5) cell growth/differentiation, (6) survival/apoptosis, (7) gene transcription/repair, (8) antigen presentation (IP-specific), (9) oxidative stress-induced cellular damage (IP-specific), and (10) cellular maturation (TPrspecific) [63-69,98-100]. 
Table 1. Some proteasome antagonists and their characteristics.

\begin{tabular}{|c|c|c|c|}
\hline Inhibitor & Properties & $\begin{array}{l}\text { Proteasomal Binding and } \\
\text { Targeted Activities }\end{array}$ & Other Cellular Effects \\
\hline Bortezomib & $\begin{array}{c}\text { First-class; FDA-approved } \\
\left(\text { Velcade }^{\circledR}\right) \text { for first-line treatment } \\
\text { of multiple myeloma }\end{array}$ & $\begin{array}{l}\text { Reversibly binds } 26 \mathrm{~S} \text { proteasome } \\
\text { and immunoproteasome; } \\
\text { chymotrypsin -> caspase -> } \\
\text { trypsin-like activity }\end{array}$ & $\begin{array}{l}\text { NF- } \mathrm{kB} \text { inhibition; cell } \\
\text { apoptosis due to } \\
\text { accumulation of proteins, } \\
\text { stress induction, and } \\
\text { disruption of cell cycle }\end{array}$ \\
\hline Carfilzomib & $\begin{array}{l}\text { New generation; FDA-approved } \\
\left(\text { Kyprolis }{ }^{\circledR}\right) \text { against relapsing } \\
\text { multiple myeloma; less toxic } \\
\text { than Bortezomib }\end{array}$ & $\begin{array}{l}\text { Irreversibly binds } 20 S \text { proteasome } \\
\text { and immunoproteasome; } \\
\text { chymotrypsin-like activity }\end{array}$ & Cell apoptosis \\
\hline Lactacystin & $\begin{array}{l}\text { Isolated from soil Actinomycetes; } \\
\text { Prodrug, metabolized into a } \\
\beta \text {-lactone (Omuralide) in vivo; } \\
\text { inhibits non-proteasome } \\
\text { proteases like cathepsin }\end{array}$ & $\begin{array}{l}\text { Irreversibly binds } 20 S \text { proteasome } \\
\text { and immunoproteasome; all } \\
\text { activities, with preference to } \\
\text { chymotrypsin-like activity }\end{array}$ & $\begin{array}{l}\text { Inhibits cellular growth; cell } \\
\text { apoptosis; NF- } \mathrm{B} \\
\text { downregulation }\end{array}$ \\
\hline Epoxomicin & $\begin{array}{l}\text { Isolated from Actinomycetes } \\
\text { strain; specific }\end{array}$ & $\begin{array}{l}\text { Irreversible binds } 20 \mathrm{~S} \text { proteasome; } \\
\text { all activities, with preference to } \\
\text { chymotrypsin-like activity }\end{array}$ & Inhibits NF- $\kappa B$ signaling \\
\hline MG132 & $\begin{array}{l}\text { Peptide aldehyde isolated from } \\
\text { Chinese medicinal herbs; first } \\
\text { choice to study UPS in human } \\
\text { cell lines }\end{array}$ & $\begin{array}{l}\text { Irreversibly binds } 20 S \text { proteasome; } \\
\text { all activities, with preference to } \\
\text { chymotrypsin-like activity }\end{array}$ & $\begin{array}{l}\text { Cell cycle arrest and apoptosis; } \\
\text { inhibits NF- } \mathrm{kB} \text { activation }\end{array}$ \\
\hline
\end{tabular}

\section{The Platelet Proteasome}

Yukawa et al. [101] were the first to purify the platelet proteasome with a chromatography column, initially reporting the presence of several subunits with chymotrypsin- and trypsin-like activities. Subsequent investigations corroborated that platelets express (1) the standard proteasome (20S and 26S) and the IP [62,82,102,103], (2) functional mono and polyubiquitination systems [104,105], (3) UPS-related mRNAs [52], and (4) DUBs [106]. Still and all, the role and modulation of proteasome-mediated protein degradation in these anucleate cell fragments remain elusive.

\subsection{Intra- and Extra-Platelet Activators and Regulators}

The platelet proteasome is constitutively active, yet multiple molecules augment its activity [69]. At relatively high concentrations, poly-lysine and SDS are considered proteasome activators. Several other natural and synthetic lipid- and peptide-based molecules are known to induce proteasomal activation as well, even at low concentrations [107]. Platelet agonists including collagen and thrombin induce, respectively, a 10- and 7-fold increase in proteasomal chymotrypsin-like activity [69]; ADP also causes the proteasomal activity to double [108]. Platelet receptors including toll-like receptor 4 (TLR4) (lipopolysaccharidesligated), PAR1 (thrombin-ligated), GPIb-IX-V (thrombin- and VWF-ligated), and P2Y 12 (ADP-ligated) communicate with the proteasome [104]. In terms of intraplatelet regulation, the activation of the proteolytic machinery proceeds through cAMP production and is PKAdependent [109]. ATP, $\mathrm{Mg}^{2+}$, PLC $\gamma$ pathway, and calcium-dependent effectors like calpain and PKC also regulate proteasomal enzymatic activity [69,101,110-112]. Yukawa et al. [101] purified form platelets an endogenous polypeptide complex $(170 \mathrm{kDa})$ that potentiates and dose-dependently enhances proteasomal chymotrypsin- and trypsin-like activities. The same group then characterized the latter 170-kDa polypeptide complex, demonstrating that it functions as a positive allosteric effector [113]. Ostrowska et al. [102] later discovered that platelets also express functional PA28 (PSME1) that controls antigen processing through stimulating proteasomal chymotryptic-like activity. 


\subsection{Roles}

As in nucleated cells, platelet proteasome performs chymotrypsin-, trypsin-, and caspase-like proteolytic activities which largely ascribe to the proteasome a regulatory role in platelet production, viability, and function [73].

\subsubsection{In Platelet Production and Viability}

The proteasome modulates platelet production and lifespan. This is evidenced in that proteasome inhibition reduces platelet count and half-life by $50 \%$. Simultaneously, changes in apoptotic markers (e.g., phosphatidylserine (PS) exposure, pro-apoptotic BAX protein upregulation, mitochondrial transmembrane potential decrease) and macrophagemediated clearance are observed $[53,114]$. Bortezomib, the first proteasome inhibitor to hit clinical practice as a second-line treatment for multiple myeloma [115], also induces thrombocytopenia in patients by influencing the production of platelets from megakaryocytes. Specifically, bortezomib use elevates the levels of activated small GTPase Rho, a negative regulator of platelet formation [116-118]. In addition, after bortezomib withdrawal, drugassociated thrombotic microangiopathy is resolved in patients [119]. These data suggest that the proteasome is involved in physiologic and pathophysiologic platelet states, overall regulating platelet thrombopoiesis and viability [120].

\subsubsection{In Platelet Function}

\section{Pathological Findings}

Examining the characteristics of the platelet proteasome in pathological settings allows us to better understand its degree of contribution to platelet function. For instance, E. coli-induced sepsis upregulates platelet PA28 on mRNA and protein levels and augments proteasomal proteolytic activity [121]. In hemolytic conditions, the increased levels of oxidative stress in platelets are associated with (1) reduced proteasomal activity and augmented protein ubiquitination, (2) increased BAX levels, and (3) premature death [122]. In coronary artery disease (CAD), patients present with decreased expression of PSMB8 [123]. In patients with ANKRD26 gene-related thrombocytopenia, proteasome-studded particulate cytoplasmic structures are observed in platelets, which additionally show reduced aggregation responses [124]. However, whether these UPS characteristics are causing factors or consequences of such pathologies requires further investigation.

\section{Pharmacological Findings}

A clearer insight into the impact of the proteasome on platelet activation was obtained by pharmacologically targeting the UPS components, primarily the standard proteasome and the proteasome-associated DUBs.

Proteasome Inhibitors

Dupré et al. [64] showed using PSI that the proteasome desensitizes platelets to the platelet-activating factor (PAF), a potent phospholipid mediator associated with multiple inflammatory diseases, via downregulating the ubiquitin-coupled PAF receptor upon ligand stimulation. Another negative regulatory role for the proteasome in platelet activation was reported. Using MG132, it was shown that the proteasome can degrade platelet CD36, a receptor for oxLDL and cell-derived microparticles [125]. Besides, platelet treatment with bortezomib was shown to attenuate VASP phosphorylation —an inhibitory signaling pathway that reduces P-selectin exposure and fibrinogen binding to the $\alpha \mathrm{IIb} \beta 3$ integrin receptor-thereby enhancing platelet aggregation [126,127].

Contrastingly, most other reports corroborate a positive regulatory role for the proteasome in platelet activation (Figure 2). Using PSI and MG132 in megakaryocytes, Mitchell et al. [128] showed that the biogenesis of $\alpha \mathrm{IIb} \beta 3$ integrin is regulated by the proteasome through the degradation of misfolded pro- $\alpha \mathrm{IIb}$ subunits. Although contravened by Koessler et al. $[108,126]$ who used different platelet agonist doses, bortezomib use conferred upon the proteolytic complex a role in collagen-mediated ATP release and 
ADP-induced platelet aggregation - the latter function being established by degrading eNOS regulators and preventing the production of NO, an ADP receptor antagonist [129]. Besides ameliorating endothelial function and blocking NF- $\mathrm{KB}$ activation in vascular and blood cells, this might explain the reduction of thromboembolic events in vivo upon proteasomal antagonism [130]. Furthermore, administering MG132 to mice, or treating their platelets with MG132 and reinjecting them, delays induced occlusive thrombosis. In vitro, this is attributed to the inhibition of cleavage of cytoskeleton regulators, such as Filamin A, which links GPIb-IX-V complex to cytoskeletal actin filaments, and Talin-1, which plays a role in platelet spreading. As such, both proteins accumulate in the cytoplasm, ubiquitinated and in their native non-cleaved form, overall causing reduced platelet (1) adherence and spreading, (2) surface release of PS-expressing prothrombotic microparticles, (3) aggregation, and (4) fibrin-platelet clot retraction, as compared to a positive control (platelets stimulated with subthreshold-dose thrombin) [104]. Likewise, Karim et al. [131] reported decreased (1) $\alpha \mathrm{IIb} \beta 3$ activation, (2) P-selectin and PS exposure (markers of platelet degranulation and procoagulant activity), (3) intracellular calcium levels, and (4) aggregation in platelets pretreated with MG132 then stimulated with subthreshold doses of collagen and/or thrombin. Noteworthy, both studies demonstrate that the levels of platelet activation markers and platelet aggregation are unaffected by proteasomal antagonism in response to higher doses of thrombin (above $0.05 \mathrm{U} / \mathrm{mL}$ ). This suggests weaker ties between the proteasome and thrombin's high-affinity receptor (PAR1) as compared to the other thrombin receptor GPIb-IX-V [104,131].

Few other studies argue that the inhibition of platelet aggregation using proteasome inhibitors does not proceed through proteasome antagonism but rather and particularly through NF- KB inhibition [135]. This observation might be explained by the fact that collagen-mediated platelet activation through the GPVI receptor is transduced through spleen tyrosine kinase (Syk) that phosphorylates several adaptor proteins in the pathway. Indeed, upon GPVI ligation, Syk is ubiquitinated but not degraded; its activity becomes 5 -fold higher, after which it is thought to modulate platelet function. Likewise, collagenrelated peptides were demonstrated to elevate the amount of ubiquitinated proteins in platelets for signaling purposes $[105,136]$. Another study showed no effect on P-selectin exposure upon proteasome inhibition [69].

Overall, the scarce data available so far suggest that the most potent platelet activation pathways are either upstream or work in parallel with the proteasome. Further studies might therefore warrant a clearer link between the proteasome and platelet activation and aggregation.

\section{DUB Inhibitors}

As aforementioned, proteasome-associated DUBs are essential for proteasomal functioning. Henceforth, in a similar manner to proteasome antagonists, proteasome-associated DUB antagonists have accredited a positive regulatory role for the proteasome in platelet activation. Gupta et al. [106] showed that treating platelets with b-AP15, a specific inhibitor of USP14 and UCHL5, significantly reduces $\alpha \mathrm{IIb} \beta 3$ activation and platelet aggregation in response to multiple platelet agonists. Interestingly, this study used high doses of agonists $(0.2 \mathrm{U} / \mathrm{mL}, 2 \mu \mathrm{g} / \mathrm{mL}$, and $5 \mu \mathrm{M}$ of thrombin, collagen, and ADP, respectively), thereby opposing previous reports showing no effect with MG132 or bortezomib pretreatment on the aggregation of platelets also stimulated with high-dose thrombin (above $0.05 \mathrm{U} / \mathrm{mL})[104,131]$ or collagen $(5 \mu \mathrm{g} / \mathrm{mL})[126]$ or on the aggregation of platelet-rich plasma (PRP) stimulated with collagen $(10 \mu \mathrm{g} / \mathrm{mL})$ or ADP $(10 \mu \mathrm{M})$ [108]. Additionally, bAP15 pretreatment diminished P-selectin exposure [106], another observation unreported with PSI- [69] or MG132-treated platelets [104,131]. These discrepancies between the data of both types of UPS antagonists might be resolved with further investigation.

Other players in UPS like E3 ligases are also reported to regulate platelet activation and signal transduction pathways through different mechanisms that were recently reviewed, along with data on the platelet IP, elsewhere [103]. 


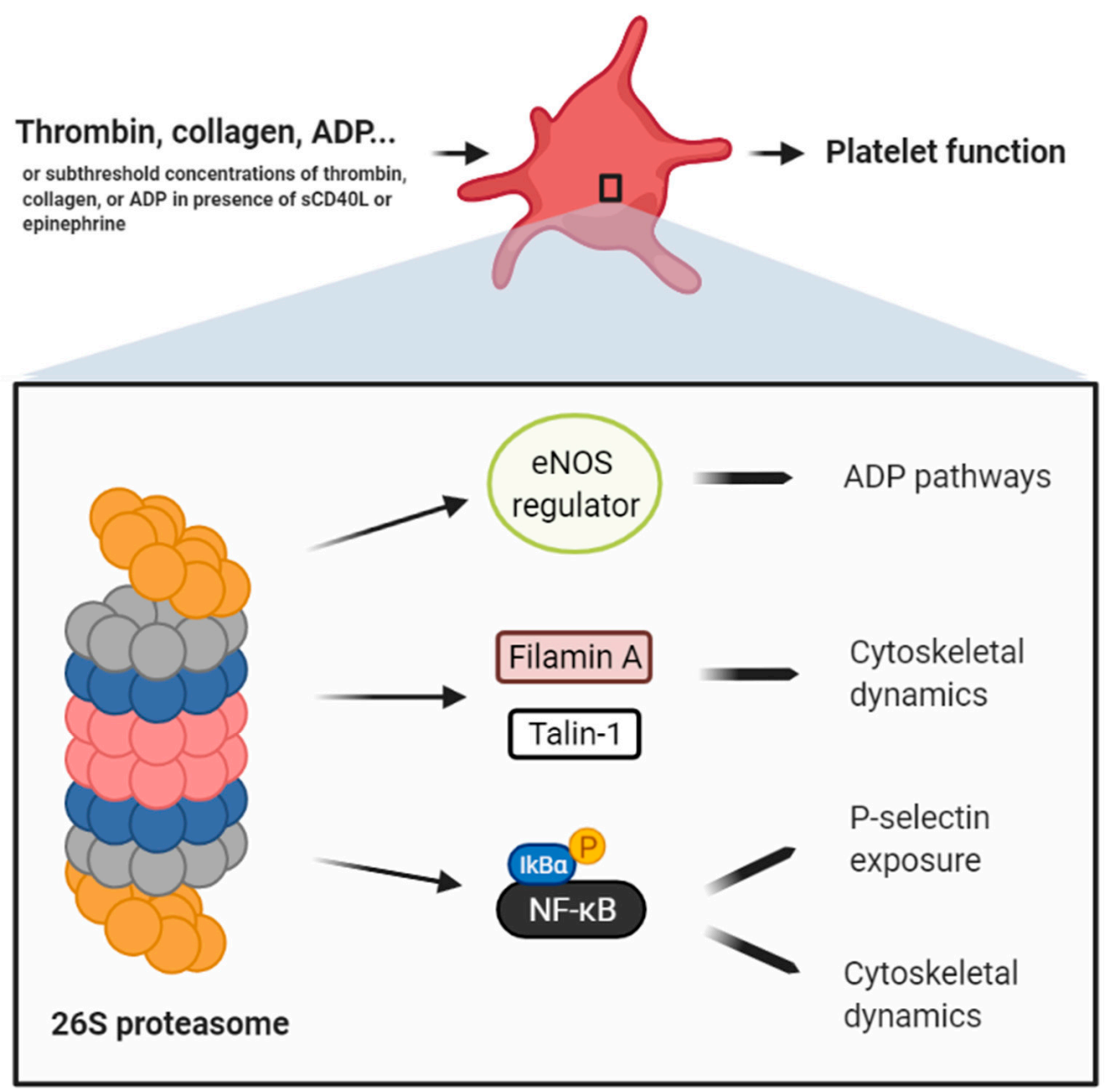

Figure 2. Schema compiling the data of different reports ascribing to the proteasome a positive regulatory role in platelets. Avcu et al. [129] claim that the platelet proteasome degrades eNOS regulators, thereby preventing the production of NO, an ADP receptor antagonist. Gupta et al. [104] showed that the proteasome, in response to the most potent platelet agonist thrombin, only partially regulates platelet function via the cleavage of cytoskeletal regulators, such as Filamin A and Talin-1. Karim et al. [131] reported that the platelet proteasome, in response to collagen or thrombin, only partially regulates platelet activation, P-selectin exposure, and aggregation, through the activation of NF- $к B$. Grundler et al. [132] showed that the platelet proteasome, in response to collagen and via NF- $\kappa B$ activation, only partially regulates platelet aggregation. Our group has shown that sCD40L primes platelets, but does not induce their aggregation, by activating platelet $\mathrm{NF}-\mathrm{KB}$ and inducing $\mathrm{P}$ selectin exposure and dynamic cytoskeletal shape changes [133,134]. sCD40L/NF-kB mediate platelet activation and aggregation in response to low doses of thrombin or collagen [134]. Although further validation is required, the sum of these data corroborates that the platelet proteasome/NF- $\mathrm{B}$ dyad is a positive regulator of platelet priming, in which P-selectin exposure and dynamic cytoskeletal shape changes are enhanced. This intermediate platelet state eventually potentiates platelet activation and aggregation when additional subthreshold concentrations of platelet agonists are secured.

\section{NF- $\mathrm{K}$ /Proteasome Coupling in Platelets}

$\mathrm{NF}-\mathrm{KB}$ is a family of cytoplasmic proteins that exist as dimers formed from five DNA-binding subunits: p50 (NF-kB1), p65 (RelA), cRel, p52 (NFkB2), and Rel B. In its canonical pathway, NF- $\mathrm{kB}$ is initially induced upon ligation of multiple receptors including tumor necrosis factor receptors, toll-like receptors, and B-cell receptors, which activate transforming growth factor $\beta$-activated kinase 1 (TAK1). In this pathway, NF- $\mathrm{kB}$ dimers are found inactivated by the inhibitory subunit IкB $\left(I_{\kappa} B \alpha\right.$ or $I_{\kappa} B \beta$, with IкB $\alpha$ being the 
most prevalent). The non-canonical pathway is triggered by several receptors including the lymphotoxin- $\beta$ receptor and the B-cell activating factor receptor, which activate the NF-kB-inducing kinase (NIK). In this pathway, NF- $\kappa B$ subunits associate with p100.

Generally, NF-kB activation requires the IкB kinase (IKK). In the canonical pathway, TAK1 activates IKK, which phosphorylates IKB, causing its ubiquitination and degradation by the proteasome (Figure 1). In the non-canonical pathway, NIK activates IKK, which phosphorylates $\mathrm{p} 100$, causing its ubiquitination and processing into $\mathrm{p} 52$ by the proteasome. Following their ubiquitination and proteasome-mediated activation, NF- $\mathrm{kB}$ dimers translocate into the nucleus, of mostly immune cells, where they bind DNA and regulate inflammatory, survival, proliferation, differentiation, transmigration, chemotaxis, and defense genes [137-139]. In fact, the genomic roles of NF-kB transcription factors in immune cells are well characterized since their discovery in B lymphocytes more than 30 years ago [140-144]. Notable, almost all NF- $\mathrm{KB}$ subunits are ubiquitinated by E3 ligases, and their ubiquitination serves as a tag not only for proteasomal degradation/processing to eventually allow the control of gene expression but also for performing other proteasomeindependent functions outside the scope of this review article $[145,146]$.

Platelets also express NF- $\mathrm{kB}$, which seems to function mainly in non-genomic ways $[42,133,134,147-153]$. Our recent extensive review article employs platelet NF$\mathrm{KB}$ as its primary focus, showcasing its role in positively regulating platelet survival, priming, activation, and aggregation as well its potential extra-platelet role following cellular endocytosis of NF- $\mathrm{kB}$-engulfing platelet microparticles [53].

In platelet function, proteasome/NF- $\mathrm{kB}$ coupling is important-a realization evident in that NF- $\mathrm{KB}$ activation necessitates the proteasome and that proteasome inhibitors are also NF- $\mathrm{kB}$ inhibitors (Table 1, Figures 1 and 2). For instance, PSI was demonstrated to inhibit collagen-induced platelet aggregation not necessarily due to inhibiting all proteasome functions [135] but specifically NF-KB activity [132]. Additionally, epoxomicin treatment of $\mathrm{PRP}$ was shown to mitigate the aggregation of collagen-stimulated platelets in an NF- $\mathrm{KB}$ dependent manner [132]. Our previous data on the functions of the platelet primer, sCD40L, show that $\mathrm{SCD} 40 \mathrm{~L}$ activates platelet NF- $\mathrm{kB}$, inducing granular secretion and so P-selectin translocation to the platelet surface [133]. We have also shown that in presence of low doses of platelet agonists, such as thrombin and collagen, sCD40L potentiates platelet aggregation through NF- $\mathrm{kB}$ activation [134]. Our most recent data validate the involvement of the proteasome/NF- $\mathrm{kB}$ dyad in the platelet priming functions of $\mathrm{SCD} 40 \mathrm{~L}$ (potentiation of platelet aggregation and fibrin-platelet clot formation) in presence of subthreshold doses of collagen and thrombin [154]. Taken together with various other reports showing that proteasome inhibition reduces platelet aggregation and/or secretion only in presence of low doses of platelet agonists $[69,104,108,126,131,149]$, it can be speculated that the proteasome/NF- $\mathrm{kB}$ dyad does not regulate platelet activation but rather platelet priming, in which platelets are not fully activated to aggregate (no Ca2+ influx or strong $\alpha \mathrm{IIb} \beta 3$ activation) but present with activation markers including P-selectin exposure and dynamic cytoskeletal shape changes [155-157]. Eventually, platelet priming potentiates platelet activation and aggregation when low doses of platelet agonists are secured [53,133,134,156,158,159].

In a pathological context, high plasma levels of platelet primers are associated with atherothrombotic disorders, such as CAD and cerebrovascular disease, which entail the highest mortality rate among the 2nd runner in death causes in Canada-cardiovascular diseases $[160,161]$. Additionally, platelet primers correlate with resistance to antiplatelet therapy like aspirin (ASA) $[157,162-166]$. Indeed, we have recently shown that ASA does not affect platelet NF- $\mathrm{kB}$ signaling induced by $\mathrm{sCD} 40 \mathrm{~L}$ alone [159]. On a similar note, the $\mathrm{NF}-\mathrm{kB}$ / proteasome dyad orchestrates chronic inflammatory diseases, such as atherothrombosis, by targeting various genes (cytokines, chemokines, immune receptors, coagulation regulators, anti-apoptotic molecules, adhesion molecules, cell cycle regulators, etc.) in thrombo-inflammatory mediators including endothelial cells, monocytes, neutrophils, lymphocytes, and platelets $[53,167,168]$. Platelets are, indeed, among the principal mediators of atherothrombotic diseases due to their adherence to atherosclerotic plaques 
and subsequent hyperactivation and secretion of multiple pro-inflammatory molecules including adhesive factors (fibrinogen, fibronectin, VWF, P-selectin), coagulation factors (factor V, factor XI, plasminogen, protein S), growth factors (platelet-derived growth factor, epidermal growth factor, basic fibroblast growth factor), and chemokines/cytokines (IL-1 $\beta$, sCD40L) [15-17,169-179]. Therefore, the NF- $\mathrm{KB} /$ proteasome dyad might maneuver the transition of platelet phenotype into chronic pro-inflammatory blood entities. Henceforth, targeting the NF- $\mathrm{kB}$ / proteasome dyad in platelets by proteasome inhibition might be therapeutically beneficial in atherothrombotic diseases, given the protective effects reported upon targeting the same dyad in other settings including myocardial infarction $[180,181]$, stroke [182], cancer [183], hypertensive injury [184], and organ transplantation [185,186].

\title{
5. Conclusions
}

Despite their anucleate nature and hand-me-down proteins from megakaryocyte precursors, platelets comprise genomic mediators like NF- $\mathrm{kB}$ and protein degradation machinery like the proteasome. The few studies available thus far on platelet proteasome show that it regulates platelet lifespan and viability yet only partially enhances platelet activation and aggregation by activating NF- $\mathrm{KB}$. In this context, the NF- $\mathrm{\kappa B}$ / proteasome dyad could be more pertinent in platelet priming, an intermediate state that predisposes platelets to pronounced activation and aggregation and correlates with atherothrombotic diseases and resistance to antiplatelet therapy. Therefore, targeting the NF- $\mathrm{KB} /$ proteasome axis in platelets might assist in contriving novel pharmacological compounds for the treatment of atherothrombosis.

Author Contributions: Conceptualization, researching, and writing A.E.-H.E.-K.; review, editing, supervision, and project administration, Y.M. All authors have read and agreed to the published version of the manuscript.

Funding: The authors acknowledge support from the Fonds de Recherche de l'Institut de Cardiologie de Montréal (FRICM) (Montreal, QC, Canada).

Institutional Review Board Statement: Not applicable.

Informed Consent Statement: Not applicable.

Acknowledgments: The authors thank all blood donors and the nursing department of the Montreal Heart Institute Biobank (Montreal, QC, Canada) for their valuable technical support in realizing our research.

Conflicts of Interest: The authors declare no conflict of interest.

\begin{abstract}
Abbreviations
ASA, aspirin; CAD, coronary artery disease; CD40L, CD40 ligand; DUB(s), deubiquitinating enzyme(s); IKK, IкB kinase; NF- $k B$, nuclear factor- $k B$; NIK, NF-kB-inducing kinase; PAF, platelet activating factor; $\mathrm{PRP}$, platelet-rich plasma; PS, phosphatidylserine; sCD40L, soluble CD40 ligand; TAK1, transforming growth factor $\beta$-activated kinase 1; TLR4, toll-like receptor 4; UPS, ubiquitin proteasome system; VWF, von Willebrand factor.
\end{abstract}

\section{References}

1. Saad, J.; Asuka, E.; Schoenberger, L. Physiology, Platelet Activation; StatPearls Publishing: Treasure Island, FL, USA, 2019.

2. Schulze, H.; Shivdasani, R.A. Mechanisms of thrombopoiesis. J. Thromb. Haemost. 2005, 3, 1717-1724. [CrossRef] [PubMed]

3. Yamada, E. The fine structure of the megakaryocyte in the mouse spleen. Cells Tissues Organs 1957, 29, 267-290. [CrossRef] [PubMed]

4. George, J.N. Platelets. Lancet 2000, 355, 1531-1539. [CrossRef]

5. Varga-Szabo, D.; Pleines, I.; Nieswandt, B. Cell adhesion mechanisms in platelets. Arterioscler. Thromb. Vasc. Biol. 2008, 28, 403-412. [CrossRef] [PubMed]

6. Van der Meijden, P.E.J.; Heemskerk, J.W.M. Platelet biology and functions: New concepts and clinical perspectives. Nat. Rev. Cardiol. 2019, 16, 166-179. [CrossRef] [PubMed] 
7. Simurda, T.; Zolkova, J.; Snahnicanova, Z.; Loderer, D.; Skornova, I.; Sokol, J.; Hudecek, J.; Stasko, J.; Lasabova, Z.; Kubisz, P. Identification of Two Novel Fibrinogen B $\beta$ Chain Mutations in Two Slovak Families with Quantitative Fibrinogen Disorders. Int. J. Mol. Sci. 2017, 19, 100. [CrossRef] [PubMed]

8. Meyer, M.W.; Gong, K.; Herzberg, M.C. Streptococcus sanguis-induced platelet clotting in rabbits and hemodynamic and cardiopulmonary consequences. Infect. Immun. 1998, 66, 5906-5914. [CrossRef]

9. Mcnicol, A.; Agpalza, A.; Jackson, E.C.G.; Hamzeh-Cognasse, H.; Garraud, O.; Cognasse, F. Streptococcus sanguinis-induced cytokine release from platelets. J. Thromb. Haemost. 2011, 9, 2038-2049. [CrossRef]

10. Clark, S.R.; Ma, A.C.; Tavener, S.A.; McDonald, B.; Goodarzi, Z.; Kelly, M.M.; Patel, K.D.; Chakrabarti, S.; McAvoy, E.; Sinclair, G.D.; et al. Platelet TLR4 activates neutrophil extracellular traps to ensnare bacteria in septic blood. Nat. Med. 2007, 13, 463-469. [CrossRef]

11. Korniluk, A.; Koper, O.; Kemona, H.; Dymicka-Piekarska, V. From inflammation to cancer. Ir. J. Med. Sci. 2017, 186, 57-62. [CrossRef]

12. Gay, L.J.; Felding-Habermann, B. Contribution of platelets to tumour metastasis. Nat. Rev. Cancer 2011, 11, 123-134. [CrossRef]

13. Prisco, D.; Paniccia, R.; Coppo, M.; Filippini, M.; Francalanci, I.; Brunelli, T.; Comeglio, P.; Abbate, R. Platelet activation and platelet lipid composition in pulmonary cancer. Prostaglandins Leukot. Essent. Fat. Acids 1995, 53, 65-68. [CrossRef]

14. Blann, A.D.; Gurney, D.; Wadley, M.; Bareford, D.; Stonelake, P.; Lip, G.Y.H. Increased soluble P-selectin in patients with haematological and breast cancer: A comparison with fibrinogen, plasminogen activator inhibitor and von Willebrand factor. Blood Coagul. Fibrinolysis 2001, 12, 43-50. [CrossRef]

15. Jennings, L.K. Role of Platelets in Atherothrombosis. Am. J. Cardiol. 2009, 103, 4A-10A. [CrossRef] [PubMed]

16. Davì, G.; Patrono, C.; Davi, G.; Patrono, C. Platelet activation and atherothrombosis. N. Engl. J. Med. 2007, 357, $2482-2492$. [CrossRef]

17. Gawaz, M.; Langer, H.; May, A.E. Platelets in inflammation and atherogenesis. J. Clin. Invest. 2005, 115, 3378-3384. [CrossRef] [PubMed]

18. Cox, D.; Kerrigan, S.W.; Watson, S.P. Platelets and the innate immune system: Mechanisms of bacterial-induced platelet activation. J. Thromb. Haemost. 2011, 9, 1097-1107. [CrossRef]

19. Shannon, O.; Hertzén, E.; Norrby-Teglund, A.; Mörgelin, M.; Sjöbring, U.; Björck, L. Severe streptococcal infection is associated with M protein-induced platelet activation and thrombus formation. Mol. Microbiol. 2007, 65, 1147-1157. [CrossRef] [PubMed]

20. Brennan, M.P.; Loughman, A.; Devocelle, M.; Arasu, S.; Chubb, A.J.; Foster, T.J.; Cox, D. Elucidating the role of Staphylococcus epidermidis serine-aspartate repeat protein G in platelet activation. J. Thromb. Haemost. 2009, 7, 1364-1372. [CrossRef]

21. Russwurm, S.; Vickers, J.; Meier-Hellmann, A.; Spangenberg, P.; Bredle, D.; Reinhart, K.; Lösche, W. Platelet and leukocyte activation correlate with the severity of septic organ dysfunction. Shock 2002, 17, 263-268. [CrossRef]

22. Koupenova, M.; Vitseva, O.; MacKay, C.R.; Beaulieu, L.M.; Benjamin, E.J.; Mick, E.; Kurt-Jones, E.A.; Ravid, K.; Freedman, J.E. Platelet-TLR7 mediates host survival and platelet count during viral infection in the absence of platelet-dependent thrombosis. Blood 2014, 124, 791-802. [CrossRef] [PubMed]

23. Aslam, R.; Speck, E.R.; Kim, M.; Crow, A.R.; Bang, K.W.A.; Nestel, F.P.; Ni, H.; Lazarus, A.H.; Freedman, J.; Semple, J.W. Platelet Toll-like receptor expression modulates lipopolysaccharide-induced thrombocytopenia and tumor necrosis factor- $\alpha$ production in vivo. Blood 2006, 107, 637-641. [CrossRef] [PubMed]

24. Andonegui, G.; Kerfoot, S.M.; McNagny, K.; Ebbert, K.V.J.; Patel, K.D.; Kubes, P. Platelets express functional Toll-like receptor-4. Blood 2005, 106, 2417-2423. [CrossRef]

25. Zucoloto, A.Z.; Jenne, C.N. Platelet-Neutrophil Interplay: Insights into Neutrophil Extracellular Trap (NET)-Driven Coagulation in Infection. Front. Cardiovasc. Med. 2019, 6. [CrossRef]

26. Kunicki, T.J. Platelet glycoprotein antigens and immune receptors. Prog. Clin. Biol. Res. 1988, 283, 87-123.

27. Michelson, A.D. Platelets; Elsevier Inc.: Amsterdam, The Netherdlands, 2013; ISBN 9780123878373.

28. Israels, S.J.; Gerrard, J.M.; Jacques, Y.V.; McNicol, A.; Cham, B.; Nishibori, M.; Bainton, D.F. Platelet dense granule membranes contain both granulophysin and P-selectin (GMP-140). Blood 1992, 80, 143-152. [CrossRef]

29. Youssefian, T.; Massé, J.M.; Rendu, F.; Guichard, J.; Cramer, E.M. Platelet and megakaryocyte dense granules contain glycoproteins $\mathrm{Ib}$ and IIb-IIIa. Blood 1997, 89, 4047-4057. [CrossRef] [PubMed]

30. White, J.G.; Conard, W.J. The fine structure of freeze-fractured blood platelets. Am. J. Pathol. 1973, 70, 45-56. [PubMed]

31. Boyles, J.; Fox, J.E.B.; Phillips, D.R.; Stenberg, P.E. Organization of the cytoskeleton in resting, discoid platelets: Preservation of actin filaments by a modified fixation that prevents osmium damage. J. Cell Biol. 1985, 101, 1463-1472. [CrossRef] [PubMed]

32. Kenney, D.M.; Linck, R.W. The cystoskeleton of unstimulated blood platelets: Structure and composition of the isolated marginal microtubular band. J. Cell Sci. 1985, 78, 1-22.

33. Hartwig, J.H. Mechanisms of actin rearrangements mediating platelet activation. J. Cell Biol. 1992, 118, 1421-1441. [CrossRef]

34. Fox, J.E.B. Linkage of a membrane skeleton to integral membrane glycoproteins in human platelets. Identification of one of the glycoproteins as glycoprotein Ib. J. Clin. Investig. 1985, 76, 1673-1683. [CrossRef] [PubMed]

35. Berger, G.; Massé, J.M.; Cramer, E.M. Alpha-granule membrane mirrors the platelet plasma membrane and contains the glycoproteins Ib, IX, and V. Blood 1996, 87, 1385-1395. [CrossRef] [PubMed]

36. Maynard, D.M.; Heijnen, H.F.G.; Horne, M.K.; White, J.G.; Gahl, W.A. Proteomic analysis of platelet $\alpha$-granules using mass spectrometry. J. Thromb. Haemost. 2007, 5, 1945-1955. [CrossRef] [PubMed] 
37. McNicol, A.; Israels, S.J. Platelet dense granules: Structure, function and implications for haemostasis. Thromb. Res. 1999, 95, 1-18. [CrossRef]

38. Handagama, P.; Scarborough, R.M.; Shuman, M.A.; Bainton, D.F. Endocytosis of fibrinogen into megakaryocyte and platelet alpha-granules is mediated by alpha IIb beta 3 (glycoprotein IIb-IIIa). Blood 1993, 82, 135-138. [CrossRef]

39. Akbiyik, F.; Ray, D.M.; Gettings, K.F.; Blumberg, N.; Francis, C.W.; Phipps, R.P. Human bone marrow megakaryocytes and platelets express PPAR $\gamma$, and PPAR $\gamma$ agonists blunt platelet release of CD40 ligand and thromboxanes. Blood 2004. [CrossRef]

40. Ali, F.Y.; Davidson, S.J.; Moraes, L.A.; Traves, S.L.; Paul-Clark, M.; Bishop-Bailey, D.; Warner, T.D.; Mitchell, J.A. Role of nuclear receptor signaling in platelets: Antithrombotic effects of PPAR $\beta$. FASEB J. 2006, 20, 326-328. [CrossRef] [PubMed]

41. Zimmerman, G.A.; Weyrich, A.S. Signal-dependent protein synthesis by activated platelets: New pathways to altered phenotype and function. Arterioscler. Thromb. Vasc. Biol. 2008, 28, s17-s24. [CrossRef] [PubMed]

42. Spinelli, S.L.; Casey, A.E.; Pollock, S.J.; Gertz, J.M.; McMillan, D.H.; Narasipura, S.D.; Mody, N.A.; King, M.R.; Maggirwar, S.B.; Francis, C.W.; et al. Platelets and megakaryocytes contain functional nuclear factor-kappaB. Arterioscler. Thromb. Vasc. Biol. 2010, 30, 591-598. [CrossRef]

43. Bugert, P.; Dugrillon, A.; Günaydin, A.; Eichler, H.; Klüter, H. Messenger RNA profiling of human platelets by microarray hybridization. Thromb. Haemost. 2003, 90, 738-748. [CrossRef]

44. McRedmond, J.P.; Park, S.D.; Reilly, D.F.; Coppinger, J.A.; Maguire, P.B.; Shields, D.C.; Fitzgerald, D.J. Integration of proteomics and genomics in platelets. A profile of platelet proteins and platelet-specific genes. Mol. Cell. Proteomics 2004, 3, 133-144. [CrossRef] [PubMed]

45. Chen, T.H.; Shih, C.Y.; Hsu, W.L.; Chou, T.C. Mechanisms of nifedipine-downregulated CD40L/sCD40L signaling in collagen stimulated human platelets. PLoS ONE 2015, 10, e0127054. [CrossRef] [PubMed]

46. Shih, C.Y.; Chou, T.C. The antiplatelet activity of magnolol is mediated by PPAR- $\beta / \gamma$. Biochem. Pharmacol. 2012, 84, 793-803. [CrossRef] [PubMed]

47. Moraes, L.A.; Swales, K.E.; Wray, J.A.; Damazo, A.; Gibbins, J.M.; Warner, T.D.; Bishop-Bailey, D. Nongenomic signaling of the retinoid X receptor through binding and inhibiting Gq in human platelets. Blood 2007, 109, 3741-3744. [CrossRef] [PubMed]

48. Ray, D.M.; Spinelli, S.L.; Pollock, S.J.; Murant, T.I.; O’Brien, J.J.; Blumberg, N.; Francis, C.W.; Taubman, M.B.; Phipps, R.P. Peroxisome proliferator-activated receptor $\gamma$ and retinoid $X$ receptor transcription factors are released from activated human platelets and shed in microparticles. Thromb. Haemost. 2008, 99, 86-95. [CrossRef]

49. Gnatenko, D.V.; Dunn, J.J.; McCorkle, S.R.; Weissmann, D.; Perrotta, P.L.; Bahou, W.F. Transcript profiling of human platelets using microarray and serial analysis of gene expression. Blood 2003, 101, 2285-2293. [CrossRef]

50. Denis, M.M.; Tolley, N.D.; Bunting, M.; Schwertz, H.; Jiang, H.; Lindemann, S.; Yost, C.C.; Rubner, F.J.; Albertine, K.H.; Swoboda, K.J.; et al. Escaping the nuclear confines: Signal-dependent pre-mRNA splicing in anucleate platelets. Cell 2005, 122, 379-391. [CrossRef]

51. Weyrich, A.S.; Schwertz, H.; Kraiss, L.W.; Zimmerman, G.A. Protein synthesis by platelets: Historical and new perspectives. J. Thromb. Haemost. 2009, 7, 241-246. [CrossRef]

52. Rowley, J.W.; Oler, A.J.; Tolley, N.D.; Hunter, B.N.; Low, E.N.; Nix, D.A.; Yost, C.C.; Zimmerman, G.A.; Weyrich, A.S. Genome-wide RNA-seq analysis of human and mouse platelet transcriptomes. Blood 2011, 118, e101-e111. [CrossRef]

53. Kojok, K.; El-Kadiry, A.E.H.; Merhi, Y. Role of NF-kB in platelet function. Int. J. Mol. Sci. 2019, 20, 4185. [CrossRef]

54. Landry, P.; Plante, I.; Ouellet, D.L.; Perron, M.P.; Rousseau, G.; Provost, P. Existence of a microRNA pathway in anucleate platelets. Nat. Struct. Mol. Biol. 2009, 16, 961-966. [CrossRef] [PubMed]

55. Gregory, R.I.; Yan, K.P.; Amuthan, G.; Chendrimada, T.; Doratotaj, B.; Cooch, N.; Shiekhattar, R. The Microprocessor complex mediates the genesis of microRNAs. Nature 2004, 432, 235-240. [CrossRef] [PubMed]

56. Nagalla, S.; Shaw, C.; Kong, X.; Kondkar, A.A.; Edelstein, L.C.; Ma, L.; Chen, J.; McKnight, G.S.; López, J.A.; Yang, L.; et al. Platelet microRNA-mRNA coexpression profiles correlate with platelet reactivity. Blood 2011, 117, 5189-5197. [CrossRef] [PubMed]

57. Plé, H.; Landry, P.; Benham, A.; Coarfa, C.; Gunaratne, P.H.; Provost, P. The Repertoire and Features of Human Platelet microRNAs. PLoS ONE 2012, 7, e50746. [CrossRef] [PubMed]

58. Osman, A.; FÄlker, K. Characterization of human platelet microRNA by quantitative PCR coupled with an annotation network for predicted target genes. Platelets 2011, 22, 433-441. [CrossRef]

59. Risitano, A.; Beaulieu, L.M.; Vitseva, O.; Freedman, J.E. Platelets and platelet-like particles mediate intercellular RNA transfer. Blood 2012, 119, 6288-6295. [CrossRef]

60. Li, J.; Tan, M.; Xiang, Q.; Zhou, Z.; Yan, H. Thrombin-activated platelet-derived exosomes regulate endothelial cell expression of ICAM-1 via microRNA-223 during the thrombosis-inflammation response. Thromb. Res. 2017, 154, 96-105. [CrossRef]

61. Barry, O.P.; Praticò, D.; Savani, R.C.; FitzGerald, G.A. Modulation of monocyte-endothelial cell interactions by platelet microparticles. J. Clin. Invest. 1998, 102, 136-144. [CrossRef]

62. Kraemer, B.F.; Weyrich, A.S.; Lindemann, S. Protein degradation systems in platelets. Thromb. Haemost. 2013, 110, 920-924. [CrossRef] [PubMed]

63. Mori, S.; Tanaka, K.; Omura, S.; Saito, Y. Degradation process of ligand-stimulated platelet-derived growth factor $\beta$-receptor involves ubiquitin-proteasome proteolytic pathway. J. Biol. Chem. 1995, 270, 29447-29452. [CrossRef]

64. Dupré, D.J.; Chen, Z.; Le Gouill, C.; Thériault, C.; Parent, J.L.; Rola-Pleszczynski, M.; Stankova, J. Trafficking, Ubiquitination, and Down-regulation of the Human Platelet-activating Factor Receptor. J. Biol. Chem. 2003, 278, 48228-48235. [CrossRef] 
65. Saur, S.J.; Sangkhae, V.; Geddis, A.E.; Kaushansky, K.; Hitchcock, I.S. Ubiquitination and degradation of the thrombopoietin receptor c-Mpl. Blood 2010, 115, 1254-1263. [CrossRef]

66. Ostrowska, H.; Wojcik, C.; Omura, S.; Worowski, K. Lactacystin, a specific inhibitor of the proteasome, inhibits human platelet lysosomal cathepsin A-like enzyme. Biochem. Biophys. Res. Commun. 1997, 234, 729-732. [CrossRef]

67. Adams, J. The proteasome: Structure, function, and role in the cell. Cancer Treat. Rev. 2003, 29, 3-9. [CrossRef]

68. Nencioni, A.; Grünebach, F.; Patrone, F.; Ballestrero, A.; Brossart, P. Proteasome inhibitors: Antitumor effects and beyond. Leukemia 2007, 21, 30-36. [CrossRef]

69. Nayak, M.K.; Kumar, K.; Dash, D. Regulation of proteasome activity in activated human platelets. Cell Calcium 2011, 49, $226-232$. [CrossRef]

70. Komander, D. The emerging complexity of protein ubiquitination. Biochem. Soc. Trans. 2009, 37, 937-953. [CrossRef] [PubMed]

71. Li, W.; Bengtson, M.H.; Ulbrich, A.; Matsuda, A.; Reddy, V.A.; Orth, A.; Chanda, S.K.; Batalov, S.; Joazeiro, C.A.P. Genome-wide and functional annotation of human E3 ubiquitin ligases identifies MULAN, a mitochondrial E3 that regulates the organelle's dynamics and signaling. PLoS ONE 2008, 3, e1487. [CrossRef] [PubMed]

72. Budenholzer, L.; Cheng, C.L.; Li, Y.; Hochstrasser, M. Proteasome Structure and Assembly. J. Mol. Biol. 2017, 429, 3500-3524. [CrossRef]

73. Coux, O.; Tanaka, K.; Goldberg, A.L. Structure and Functions of the 20S and 26S Proteasomes. Annu. Rev. Biochem. 1996, 65, 801-847. [CrossRef] [PubMed]

74. Tanaka, K.; Mizushima, T.; Saeki, Y. The proteasome: Molecular machinery and pathophysiological roles. Biol. Chem. 2012, 393, 217-234. [CrossRef] [PubMed]

75. Ciechanover, A. The ubiquitin-proteasome proteolytic pathway. Cell 1994, 79, 13-21. [CrossRef]

76. Kisselev, A.F.; Goldberg, A.L. Proteasome inhibitors: From research tools to drug candidates. Chem. Biol. 2001, 8, 739-758. [CrossRef]

77. Bedford, L.; Hay, D.; Devoy, A.; Paine, S.; Powe, D.G.; Seth, R.; Gray, T.; Topham, I.; Fone, K.; Rezvani, N.; et al. Depletion of $26 \mathrm{~S}$ proteasomes in mouse brain neurons causes neurodegeneration and lewy-like inclusions resembling human pale bodies. J. Neurosci. 2008, 28, 8189-8198. [CrossRef]

78. Mofers, A.; Pellegrini, P.; Linder, S.; D'Arcy, P. Proteasome-associated deubiquitinases and cancer. Cancer Metastasis Rev. 2017, 36, 635-653. [CrossRef]

79. Reyes-Turcu, F.E.; Ventii, K.H.; Wilkinson, K.D. Regulation and Cellular Roles of Ubiquitin-Specific Deubiquitinating Enzymes. Annu. Rev. Biochem. 2009, 78, 363-397. [CrossRef]

80. Murata, S.; Takahama, Y.; Kasahara, M.; Tanaka, K. The immunoproteasome and thymoproteasome: Functions, evolution and human disease. Nat. Immunol. 2018, 19, 923-931. [CrossRef]

81. Vigneron, N.; Van den Eynde, B.J. Proteasome subtypes and regulators in the processing of antigenic peptides presented by class I molecules of the major histocompatibility complex. Biomolecules 2014, 4, 994-1025. [CrossRef]

82. Klockenbusch, C.; Walsh, G.M.; Brown, L.M.; Hoffman, M.D.; Ignatchenko, V.; Kislinger, T.; Kast, J. Global proteome analysis identifies active immunoproteasome subunits in human platelets. Mol. Cell. Proteomics 2014, 13, 3308-3319. [CrossRef]

83. Kniepert, A.; Groettrup, M. The unique functions of tissue-specific proteasomes. Trends Biochem. Sci. 2014, 39, 17-24. [CrossRef] [PubMed]

84. Liepe, J.; Holzhutter, H.G.; Kloetzel, P.M.; Stumpf, M.P.H.; Mishto, M. Modelling proteasome and proteasome regulator activities. Biomolecules 2014, 4, 585-599. [CrossRef]

85. Sun, Y.; Sijts, A.J.A.M.; Song, M.; Janek, K.; Nussbaum, A.K.; Kral, S.; Schirle, M.; Stevanovic, S.; Paschen, A.; Schild, H.; et al. Expression of the proteasome activator PA28 rescues the presentation of a cytotoxic T lymphocyte epitope on melanoma cells. Cancer Res. 2002, 62, 2875-2882.

86. Wang, J.; Wang, C.E.; Orr, A.; Tydlacka, S.; Li, S.H.; Li, X.J. Impaired ubiquitin-proteasome system activity in the synapses of Huntington's disease mice. J. Cell Biol. 2008, 180, 1177-1189. [CrossRef] [PubMed]

87. Lowe, J.; Blanchard, A.; Morrell, K.; Lennox, G.; Reynolds, L.; Billett, M.; Landon, M.; Mayer, R.J. Ubiquitin is a common factor in intermediate filament inclusion bodies of diverse type in man, including those of Parkinson's disease, Pick's disease, and Alzheimer's disease, as well as Rosenthal fibres in cerebellar astrocytomas, cytoplasmic bodies in muscle, and mallory bodies in alcoholic liver disease. J. Pathol. 1988, 155, 9-15. [CrossRef]

88. Giasson, B.I.; Lee, V.M. Parkin and the molecular pathways of Parkinson's disease. Neuron 2001, 31, 885-888. [CrossRef]

89. Kourtis, N.; Tavernarakis, N. Cellular stress response pathways and ageing: Intricate molecular relationships. EMBO J. 2011, 30, 2520-2531. [CrossRef] [PubMed]

90. Kim, H.; Sanchez, G.A.M.; Goldbach-Mansky, R. Insights from Mendelian Interferonopathies: Comparison of CANDLE, SAVI with AGS, Monogenic Lupus. J. Mol. Med. 2016, 94, 1111-1127. [CrossRef] [PubMed]

91. Kubiczkova, L.; Pour, L.; Sedlarikova, L.; Hajek, R.; Sevcikova, S. Proteasome inhibitors - molecular basis and current perspectives in multiple myeloma. J. Cell. Mol. Med. 2014, 18, 947-961. [CrossRef] [PubMed]

92. Ōmura, S.; Crump, A. Lactacystin: First-in-class proteasome inhibitor still excelling and an exemplar for future antibiotic research. J. Antibiot. 2019, 72, 189-201. [CrossRef] [PubMed]

93. Guo, N.; Peng, Z. MG132, a proteasome inhibitor, induces apoptosis in tumor cells. Asia. Pac. J. Clin. Oncol. 2013, 9, 6-11. [CrossRef] 
94. Meng, L.; Mohan, R.; Kwok, B.H.B.; Elofsson, M.; Sin, N.; Crews, C.M. Epoxomicin, a potent and selective proteasome inhibitor, exhibits in vivo antiinflammatory activity. Proc. Natl. Acad. Sci. USA 1999, 96, 10403-10408. [CrossRef] [PubMed]

95. Craiu, A.; Gaczynska, M.; Akopian, T.; Gramm, C.F.; Fenteany, G.; Goldberg, A.L.; Rock, K.L. Lactacystin and clasto-lactacystin $\beta$-lactone modify multiple proteasome $\beta$-subunits and inhibit intracellular protein degradation and major histocompatibility complex class I antigen presentation. J. Biol. Chem. 1997, 272, 13437-13445. [CrossRef] [PubMed]

96. Prasad, R.; Atul; Kolla, V.K.; Legac, J.; Singhal, N.; Navale, R.; Rosenthal, P.J.; Sijwali, P.S. Blocking Plasmodium falciparum development via dual inhibition of hemoglobin degradation and the ubiquitin proteasome system by MG132. PLoS ONE 2013, 8, e73530. [CrossRef] [PubMed]

97. Han, Y.H.; Moon, H.J.; You, B.R.; Park, W.H. The effect of MG132, a proteasome inhibitor on HeLa cells in relation to cell growth, reactive oxygen species and GSH. Oncol. Rep. 2009, 22, 215-221. [CrossRef]

98. Seifert, U.; Bialy, L.P.; Ebstein, F.; Bech-Otschir, D.; Voigt, A.; Schröter, F.; Prozorovski, T.; Lange, N.; Steffen, J.; Rieger, M.; et al. Immunoproteasomes preserve protein homeostasis upon interferon-induced oxidative stress. Cell 2010, 142, 613-624. [CrossRef]

99. Ebstein, F.; Voigt, A.; Lange, N.; Warnatsch, A.; Schröter, F.; Prozorovski, T.; Kuckelkorn, U.; Aktas, O.; Seifert, U.; Kloetzel, P.M.; et al. Immunoproteasomes are important for proteostasis in immune responses. Cell 2013, 152, 935-937. [CrossRef]

100. Groettrup, M.; Kirk, C.J.; Basler, M. Proteasomes in immune cells: More than peptide producers? Nat. Rev. Immunol. 2010, 10, 73-78. [CrossRef]

101. Yukawa, M.; Sakon, M.; Kambayashi, J.; Shiba, E.; Kawasaki, T.; Ariyoshi, H.; Mori, T. Proteasome and its novel endogeneous activator in human platelets. Biochem. Biophys. Res. Commun. 1991, 178, 256-262. [CrossRef]

102. Ostrowska, H.; Ostrowska, J.K.; Worowski, K.; Radziwon, P. Human platelet 20S proteasome: Inhibition of its chymotrypsin-like activity and identification of the proteasome activator PA28. A preliminary report. Platelets 2003, 14, 151-157. [CrossRef]

103. Colberg, L.; Cammann, C.; Greinacher, A.; Seifert, U. Structure and function of the ubiquitin-proteasome system in platelets. J. Thromb. Haemost. 2020, 18, 771-780. [CrossRef]

104. Gupta, N.; Li, W.; Willard, B.; Silverstein, R.L.; McIntyre, T.M. Proteasome proteolysis supports stimulated platelet function and thrombosis. Arterioscler. Thromb. Vasc. Biol. 2014, 34, 160-168. [CrossRef] [PubMed]

105. Unsworth, A.J.; Bombik, I.; Pinto-Fernandez, A.; McGouran, J.F.; Konietzny, R.; Zahedi, R.P.; Watson, S.P.; Kessler, B.M.; Pears, C.J. Human Platelet Protein Ubiquitylation and Changes following GPVI Activation. Thromb. Haemost. 2019, 119, 104-116. [CrossRef] [PubMed]

106. Gupta, N.; Li, W.; McIntyre, T.M. Deubiquitinases Modulate Platelet Proteome Ubiquitination, Aggregation, and Thrombosis. Arterioscler. Thromb. Vasc. Biol. 2015, 35, 2657-2666. [CrossRef] [PubMed]

107. Huang, L.; Chen, C.H. Proteasome regulators: Activators and inhibitors. Curr. Med. Chem. 2009, 16, 931-939. [CrossRef] [PubMed]

108. Koessler, J.; Etzel, J.; Weber, K.; Boeck, M.; Kobsar, A. Evaluation of dose-dependent effects of the proteasome inhibitor bortezomib in human platelets. Eur. J. Pharmacol. 2016, 791, 99-104. [CrossRef]

109. Pereira, M.E.; Wilk, S. Phosphorylation of the multicatalytic proteinase complex from bovine pituitaries by a copurifying cAMP-dependent protein kinase. Arch. Biochem. Biophys. 1990, 283, 68-74. [CrossRef]

110. Tanaka, K.; Ichihara, A. Proteasomes (Multicatalytic Proteinase Complexes) in Eukaryotic Cells. Cell Struct. Funct. 1990, 15, 127-132. [CrossRef]

111. Orlowski, M. The Multicatalytic Proteinase Complex, a Major Extralysosomal Proteolytic System. Biochemistry 1990, 29, 10289_ 10297. [CrossRef] [PubMed]

112. Driscoll, J.; Goldberg, A.L. Skeletal muscle proteasome can degrade proteins in an ATP-dependent process that does not require ubiquitin. Proc. Natl. Acad. Sci. USA 1989, 86, 787-791. [CrossRef] [PubMed]

113. Yukawa, M.; Sakon, M.; Kambayashi, J.I.; Shiba, E.I.; Kawasaki, T.; Uemura, Y.; Murata, R.; Tanaka, T.; Nakayama, T.; Shibata, H.; et al. Purification and characterization of endogenous protein activator of human platelet proteasome. J. Biochem. 1993, 114, 317-323. [CrossRef]

114. Nayak, M.K.; Kulkarni, P.P.; Dash, D. Regulatory role of proteasome in determination of platelet life span. J. Biol. Chem. 2013, 288, 6826-6834. [CrossRef]

115. Caravita, T.; de Fabritiis, P.; Palumbo, A.; Amadori, S.; Boccadoro, M. Bortezomib: Efficacy comparisons in solid tumors and hematologic malignancies. Nat. Clin. Pract. Oncol. 2006, 3, 374-387. [CrossRef]

116. Lonial, S.; Waller, E.K.; Richardson, P.G.; Jagannath, S.; Orlowski, R.Z.; Giver, C.R.; Jaye, D.L.; Francis, D.; Giusti, S.; Torre, C.; et al. Risk factors and kinetics of thrombocytopenia associated with bortezomib for relapsed, refractory multiple myeloma. Blood 2005, 106, 3777-3784. [CrossRef]

117. Murai, K.; Kowata, S.; Shimoyama, T.; Yashima-Abo, A.; Fujishima, Y.; Ito, S.; Ishida, Y. Bortezomib induces thrombocytopenia by the inhibition of proplatelet formation of megakaryocytes. Eur. J. Haematol. 2014, 93, 290-296. [CrossRef] [PubMed]

118. Shi, D.S.; Smith, M.C.P.; Campbell, R.A.; Zimmerman, P.W.; Franks, Z.B.; Kraemer, B.F.; Machlus, K.R.; Ling, J.; Kamba, P.; Schwertz, H.; et al. Proteasome function is required for platelet production. J. Clin. Invest. 2014, 124, 3757-3766. [CrossRef] [PubMed]

119. Yui, J.C.; Van Keer, J.; Weiss, B.M.; Waxman, A.J.; Palmer, M.B.; D’Agati, V.D.; Kastritis, E.; Dimopoulos, M.A.; Vij, R.; Bansal, D.; et al. Proteasome inhibitor associated thrombotic microangiopathy. Am. J. Hematol. 2016, 91, E348-E352. [CrossRef] [PubMed] 
120. Kraemer, B.F.; Weyrich, A.S. Insight Increased formation of PaCSs in megakaryocytes and platelets from patients with autosomaldominant ANKRD26-related thrombocytopenia: Polyubiquinated protein depots in platelets and megakaryocytes from patients with ANKRD26-RT. Thromb. Haemost. 2012, 109, 180. [CrossRef] [PubMed]

121. Grundler Groterhorst, K.; Mannell, H.; Pircher, J.; Kraemer, B.F. Platelet Proteasome Activity and Metabolism Is Upregulated during Bacterial Sepsis. Int. J. Mol. Sci. 2019, 20, 5961. [CrossRef]

122. NaveenKumar, S.K.; Hemshekhar, M.; Kemparaju, K.; Girish, K.S. Hemin-induced platelet activation and ferroptosis is mediated through ROS-driven proteasomal activity and inflammasome activation: Protection by Melatonin. Biochim. Biophys. Acta Mol. Basis Dis. 2019, 1865, 2303-2316. [CrossRef] [PubMed]

123. Banfi, C.; Brioschi, M.; Marenzi, G.; De Metrio, M.; Camera, M.; Mussoni, L.; Tremoli, E. Proteome of platelets in patients with coronary artery disease. Exp. Hematol. 2010, 38, 341-350. [CrossRef]

124. Necchi, V.; Balduini, A.; Noris, P.; Barozzi, S.; Sommi, P.; di Buduo, C.; Balduini, C.L.; Solcia, E.; Pecci, A. Ubiquitin/proteasomerich particulate cytoplasmic structures (PaCSs) in the platelets and megakaryocytes of ANKRD26-related thrombocytopenia. Thromb. Haemost. 2013, 109, 263-271. [CrossRef]

125. Srikanthan, S.; Li, W.; Silverstein, R.L.; Mcintyre, T.M. Exosome poly-ubiquitin inhibits platelet activation, downregulates CD36 and inhibits pro-atherothombotic cellular functions. J. Thromb. Haemost. 2014, 12, 1906-1917. [CrossRef] [PubMed]

126. Koessler, J.; Schuepferling, A.; Klingler, P.; Koessler, A.; Weber, K.; Boeck, M.; Kobsar, A. The role of proteasome activity for activating and inhibitory signalling in human platelets. Cell Signal. 2019, 62, 109351. [CrossRef]

127. Klingler, P.; Niklaus, M.; Koessler, J.; Weber, K.; Koessler, A.; Boeck, M.; Kobsar, A. Influence of long-term proteasome inhibition on platelet responsiveness mediated by bortezomib. Vascul. Pharmacol. 2021, 1-11. [CrossRef]

128. Mitchell, W.B.; Li, J.; French, D.L.; Coller, B.S. $\alpha \mathrm{IIb} \beta 3$ biogenesis is controlled by engagement of $\alpha \mathrm{IIb}$ in the calnexin cycle via the N15-linked glycan. Blood 2006, 107, 2713-2719. [CrossRef]

129. Avcu, F.; Ural, A.U.; Cetin, T.; Nevruz, O. Effects of bortezomib on platelet aggregation and ATP release in human platelets, in vitro. Thromb. Res. 2008, 121, 567-571. [CrossRef] [PubMed]

130. Zhang, L.; Zhang, Z.G.; Liu, X.; Hozeska, A.; Stagliano, N.; Riordan, W.; Lu, M.; Chopp, M. Treatment of embolic stroke in rats with bortezomib and recombinant human tissue plasminogen activator. Thromb. Haemost. 2006, 95, 166-173. [CrossRef]

131. Karim, Z.A.; Vemana, H.P.; Khasawneh, F.T. MALT1-ubiquitination triggers non-genomic NF- $\mathrm{kB} / \mathrm{IKK}$ signaling upon platelet activation. PLoS ONE 2015, 10, e0119363. [CrossRef] [PubMed]

132. Grundler, K.; Rotter, R.; Tilley, S.; Pircher, J.; Czermak, T.; Yakac, M.; Gaitzsch, E.; Massberg, S.; Krötz, F.; Sohn, H.-Y.Y.; et al. The proteasome regulates collagen-induced platelet aggregation via nuclear-factor-kappa-B (NFkB) activation. Thromb. Res. 2016, 148, 15-22. [CrossRef] [PubMed]

133. Hachem, A.; Yacoub, D.; Zaid, Y.; Mourad, W.; Merhi, Y. Involvement of nuclear factor кB in platelet CD40 signaling. Biochem. Biophys. Res. Commun. 2012, 425, 58-63. [CrossRef]

134. Kojok, K.; El Akoum, S.; Mohsen, M.; Mourad, W.; Merhi, Y. CD40L Priming of Platelets via NF-kB Activation is CD40- and TAK1-Dependent. J. Am. Heart Assoc. 2018, 7, e03677. [CrossRef]

135. Ostrowska, J.K.; Wojtukiewicz, M.Z.; Chabielska, E.; Buczko, W.; Ostrowska, H. Proteasome inhibitor prevents experimental arterial thrombosis in renovascular hypertensive rats. Thromb. Haemost. 2004, 92, 171-177. [CrossRef]

136. Brophy, T.M.; Raab, M.; Daxecker, H.; Culligan, K.G.; Lehmann, I.; Chubb, A.J.; Treumann, A.; Moran, N. RN181, a novel ubiquitin E3 ligase that interacts with the KVGFFKR motif of platelet integrin $\alpha \mathrm{IIb} \beta 3$. Biochem. Biophys. Res. Commun. 2008, 369, 1088-1093. [CrossRef] [PubMed]

137. Gilmore, T.D. Introduction to NF-кB: Players, pathways, perspectives. Oncogene 2006, 25, 6680-6684. [CrossRef] [PubMed]

138. Arenzana-Seisdedos, F.; Turpin, P.; Rodriguez, M.; Thomas, D.; Hay, R.T.; Virelizier, J.L.; Dargemont, C. Nuclear localization of I $\mathrm{B} \alpha$ promotes active transport of NF-kB from the nucleus to the cytoplasm. J. Cell Sci. 1997, 110, 369-378.

139. Tanaka, M.; Fuentes, M.E.; Yamaguchi, K.; Durnin, M.H.; Dalrymple, S.A.; Hardy, K.L.; Goeddel, D.V. Embryonic lethality, liver degeneration, and impaired NF- $\mathrm{KB}$ activation in IKK- $\beta$-deficient mice. Immunity 1999, 10, 421-429. [CrossRef]

140. Morgan, M.J.; Liu, Z.G. Crosstalk of reactive oxygen species and NF-kB signaling. Cell Res. 2011, 21, 103-115. [CrossRef] [PubMed]

141. Hayden, M.S.; Ghosh, S. Shared Principles in NF-кB Signaling. Cell 2008, 132, 344-362. [CrossRef]

142. Senftleben, U.; Cao, Y.; Xiao, G.; Greten, F.R.; Krahn, G.; Bonizzi, G.; Chen, Y.; Hu, Y.; Fong, A.; Sun, S.C.; et al. Activation by IKKalpha of a second, evolutionary conserved, NF-kappa B signaling pathway. Science 2001, 293, 1495-1499. [CrossRef] [PubMed]

143. Vallabhapurapu, S.; Karin, M. Regulation and Function of NF-kB Transcription Factors in the Immune System. Annu. Rev. Immunol. 2009, 27, 693-733. [CrossRef] [PubMed]

144. Sen, R.; Baltimore, D. Multiple nuclear factors interact with the immunoglobulin enhancer sequences. Cell 1986, 46, 705-716. [CrossRef]

145. Saccani, S.; Marazzi, I.; Beg, A.A.; Natoli, G. Degradation of promoter-bound p65/RelA is essential for the prompt termination of the nuclear factor $\kappa$ B response. J. Exp. Med. 2004, 200, 107-113. [CrossRef]

146. Collins, P.; Mitxitorena, I.; Carmody, R. The Ubiquitination of NF-kB Subunits in the Control of Transcription. Cells 2016, 5, 23. [CrossRef]

147. Karim, Z.A.; Zhang, J.; Banerjee, M.; Chicka, M.C.; Al Hawas, R.; Hamilton, T.R.; Roche, P.A.; Whiteheart, S.W. IkB kinase phosphorylation of SNAP-23 controls platelet secretion. Blood 2013, 121, 4567-4574. [CrossRef] 
148. Wei, S.; Wang, H.; Zhang, G.; Lu, Y.; An, X.; Ren, S.; Wang, Y.; Chen, Y.; White, J.G.; Zhang, C.; et al. Platelet IkB kinase- $\beta$ deficiency increases mouse arterial neointima formation via delayed glycoprotein ib $\alpha$ shedding. Arterioscler. Thromb. Vasc. Biol. 2013, 33, 241-248. [CrossRef] [PubMed]

149. Hsia, C.-W.; Wu, M.-P.; Shen, M.-Y.; Hsia, C.-H.; Chung, C.-L.; Sheu, J.-R. Regulation of Human Platelet Activation and Prevention of Arterial Thrombosis in Mice by Auraptene through Inhibition of NF-kB Pathway. Int. J. Mol. Sci. 2020, 21, 4810. [CrossRef] [PubMed]

150. Chang, C.C.; Lu, W.J.; Ong, E.T.; Chiang, C.W.; Lin, S.C.; Huang, S.Y.; Sheu, J.R. A novel role of sesamol in inhibiting NF-KBmediated signaling in platelet activation. J. Biomed. Sci. 2011, 18, 93. [CrossRef]

151. Malaver, E.; Romaniuk, M.A.; D’atri, L.P.; Pozner, R.G.; Negrotto, S.; Benzadon, R.; Schattner, M. NF-kB inhibitors impair platelet activation responses. J. Thromb. Haemost. 2009, 7, 1333-1343. [CrossRef]

152. Lu, W.J.; Lin, K.H.; Hsu, M.J.; Chou, D.S.; Hsiao, G.; Sheu, J.R. Suppression of NF-kB signaling by andrographolide with a novel mechanism in human platelets: Regulatory roles of the p38 MAPK-hydroxyl radical-ERK2 cascade. Biochem. Pharmacol. 2012, 84, 914-924. [CrossRef]

153. Lee, H.S.; Kim, S.D.; Lee, W.M.; Endale, M.; Kamruzzaman, S.M.; Oh, W.J.; Cho, J.Y.; Kim, S.K.; Cho, H.J.; Park, H.J.; et al. A noble function of BAY 11-7082: Inhibition of platelet aggregation mediated by an elevated cAMP-induced VASP, and decreased ERK2/JNK1 phosphorylations. Eur. J. Pharmacol. 2010, 627, 85-91. [CrossRef]

154. El-Kadiry, A.E.-H. L'Axe SCD40L/NF-кB/Protéasome est un Amorceur des Fonctions Plaquettaires. Masters's Thesis, Université de Montréal, Montreal, QC, Canada, 2020.

155. Gresele, P.; Falcinelli, E.; Momi, S. Potentiation and priming of platelet activation: A potential target for antiplatelet therapy. Trends Pharmacol. Sci. 2008, 29, 352-360. [CrossRef]

156. Yacoub, D.; Hachem, A.; Théorêt, J.-F.; Gillis, M.-A.; Mourad, W.; Merhi, Y. Enhanced levels of soluble CD40 ligand exacerbate platelet aggregation and thrombus formation through a CD40-dependent tumor necrosis factor receptor-associated factor2/Rac1/p38 mitogen-activated protein kinase signaling pathway. Arterioscler. Thromb. Vasc. Biol. 2010, 30, 2424-2433. [CrossRef]

157. Blair, T.A.; Moore, S.F.; Hers, I. Circulating primers enhance platelet function and induce resistance to antiplatelet therapy. J. Thromb. Haemost. 2015, 13, 1479-1493. [CrossRef]

158. Yacoub, D.; Hassan, G.S.; Alaadine, N.; Merhi, Y.; Mourad, W. CD40 Ligand and Its Receptors in Atherothrombosis. In Traditional and Novel Risk Factors in Atherothrombosis; Gaxiola, E., Ed.; InTech: London, UK, 2012; p. 82. ISBN 978-953-51-0561-9.

159. Kojok, K.; Mohsen, M.; El Kadiry, A.E.H.; Mourad, W.; Merhi, Y. Aspirin Reduces the Potentiating Effect of CD40L on Platelet Aggregation via Inhibition of Myosin Light Chain. J. Am. Heart Assoc. 2020, 9. [CrossRef]

160. World Health Organization Cardiovascular Diseases. Available online: https:/ /www.who.int/health-topics/cardiovasculardiseases/\#tab=tab_1 (accessed on 14 December 2019).

161. Health Canada Heart Disease in Canada. Available online: https://www.canada.ca/en/public-health/services/publications/ diseases-conditions / heart-disease-canada.html (accessed on 14 December 2019).

162. Heeschen, C.; Dimmeler, S.; Hamm, C.W.; Van den Brand, M.J.; Boersma, E.; Zeiher, A.M.; Simoons, M.L. Soluble CD40 ligand in acute coronary syndromes. N. Engl. J. Med. 2003, 348, 1104-1111. [CrossRef] [PubMed]

163. Cipollone, F.; Mezzetti, A.; Porreca, E.; Di Febbo, C.; Nutini, M.; Fazia, M.; Falco, A.; Cuccurullo, F.; Davì, G. Association between enhanced soluble CD40L and prothrombotic state in hypercholesterolemia: Effects of statin therapy. Circulation 2002, 106, 399-402. [CrossRef]

164. Lobbes, M.B.I.; Lutgens, E.; Heeneman, S.; Cleutjens, K.B.J.M.; Kooi, M.E.; van Engelshoven, J.M.A.; Daemen, M.J.A.P.; Nelemans, P.J. Is there more than C-reactive protein and fibrinogen? The prognostic value of soluble CD40 ligand, interleukin- 6 and oxidized low-density lipoprotein with respect to coronary and cerebral vascular disease. Atherosclerosis 2006, 187, 18-25. [CrossRef]

165. Michel, N.A.; Zirlik, A.; Wolf, D. CD40L and Its Receptors in Atherothrombosis-An Update. Front. Cardiovasc. Med. 2017, 4. [CrossRef]

166. Zhang, B.; Wu, T.; Chen, M.; Zhou, Y.; Yi, D.; Guo, R. The CD40/CD40L system: A new therapeutic target for disease. Immunol. Lett. 2013, 153, 58-61. [CrossRef]

167. Mussbacher, M.; Salzmann, M.; Brostjan, C.; Hoesel, B.; Schoergenhofer, C.; Datler, H.; Hohensinner, P.; Basílio, J.; Petzelbauer, P.; Assinger, A.; et al. Cell type specific roles of nf-kb linking inflamation and thrombosis. Front. Immunol. 2019, 10. [CrossRef] [PubMed]

168. Liu, T.; Zhang, L.; Joo, D.; Sun, S.C. NF-kB signaling in inflammation. Signal Transduct. Target. Ther. 2017, 2, e17023. [CrossRef]

169. Kaplan, Z.S.; Jackson, S.P. The role of platelets in atherothrombosis. Hematol. Am. Soc. Hematol. Educ. Program 2011, $2011,51-61$. [CrossRef]

170. Jin, R.C.; Voetsch, B.; Loscalzo, J. Endogenous mechanisms of inhibition of platelet function. Microcirculation 2005, 12, 247-258. [CrossRef] [PubMed]

171. Schönbeck, U.; Libby, P. CD40 signaling and plaque instability. Circ. Res. 2001, 89, 1092-1103. [CrossRef] [PubMed]

172. Li, G.; Sanders, J.M.; Phan, E.T.; Ley, K.; Sarembock, I.J. Arterial macrophages and regenerating endothelial cells express P-selectin in atherosclerosis-prone apolipoprotein E-deficient mice. Am. J. Pathol. 2005, 167, 1511-1518. [CrossRef]

173. Schönbeck, U.; Sukhova, G.K.; Shimizu, K.; Mach, F.; Libby, P. Inhibition of CD40 signaling limits evolution of established atherosclerosis in mice. Proc. Natl. Acad. Sci. USA 2000, 97, 7458-7463. [CrossRef]

174. Gutstein, D.E.; Fuster, V. Pathophysiology and clinical significance of atherosclerotic plaque rupture. Cardiovasc. Res. 1999, 41, 323-333. [CrossRef] 
175. Zhou, J.; Chew, M.; Ravn, H.B.; Falk, E. Plaque pathology and coronary thrombosis in the pathogenesis of acute coronary syndromes. Scand. J. Clin. Lab. Investig. Suppl. 1999, 59, 3-11. [CrossRef]

176. Heemskerk, J.W.M.; Bevers, E.M.; Lindhout, T. Platelet activation and blood coagulation. Thromb. Haemost. 2002, 88, 186-193. [CrossRef] [PubMed]

177. Nesbitt, W.S.; Westein, E.; Tovar-Lopez, F.J.; Tolouei, E.; Mitchell, A.; Fu, J.; Carberry, J.; Fouras, A.; Jackson, S.P. A shear gradient-dependent platelet aggregation mechanism drives thrombus formation. Nat. Med. 2009, 15, 665-673. [CrossRef]

178. Davies, M.J. A macro and micro view of coronary vascular insult in ischemic heart disease. Circulation 1990, 82, II38-II46. [PubMed]

179. Simurda, T.; Dobrotova, M.; Skornova, I.; Sokol, J.; Kubisz, P.; Stasko, J. Successful Use of a Highly Purified Plasma von Willebrand Factor Concentrate Containing Little FVIII for the Long-Term Prophylaxis of Severe (Type 3) von Willebrand's Disease. Semin. Thromb. Hemost. 2017, 43, 639-641. [CrossRef] [PubMed]

180. Jialin, B.A.O.; Sato, K.; Min, L.I.; Youhe, G.A.O.; Abid, R.; Aird, W.; Simons, M.; Post, M.J. PR-39 and PR-11 peptides inhibit ischemia-reperfusion injury by blocking proteasome-mediated $\mathrm{I} \kappa \mathrm{B} \alpha$ degradation. Am. J. Physiol. Hear. Circ. Physiol. 2001, 281, H2612-H2618. [CrossRef]

181. Pye, J.; Ardeshirpour, F.; McCain, A.; Bellinger, D.A.; Merricks, E.; Adams, J.; Elliott, P.J.; Pien, C.; Fischer, T.H.; Baldwin, A.S.; et al. Proteasome inhibition ablates activation of NF- $\mathrm{B}$ in myocardial reperfusion and reduces reperfusion injury. Am. J. Physiol. Hear. Circ. Physiol. 2003, 284, H919-H926. [CrossRef] [PubMed]

182. Williams, A.J.; Dave, J.R.; Tortella, F.C. Neuroprotection with the proteasome inhibitor MLN519 in focal ischemic brain injury: Relation to nuclear factor $\mathrm{\kappa B}(\mathrm{NF}-\mathrm{kB})$, inflammatory gene expression, and leukocyte infiltration. Neurochem. Int. 2006, 49, 106-112. [CrossRef]

183. Schumacher, L.Y.; Vo, D.D.; Garban, H.J.; Comin-Anduix, B.; Owens, S.K.; Dissette, V.B.; Glaspy, J.A.; McBride, W.H.; Bonavida, B.; Economou, J.S.; et al. Immunosensitization of Tumor Cells to Dendritic Cell-Activated Immune Responses with the Proteasome Inhibitor Bortezomib (PS-341, Velcade). J. Immunol. 2006, 176, 4757-4765. [CrossRef]

184. Takaoka, M.; Ohkita, M.; Itoh, M.; Kobayashi, Y.; Okamoto, H.; Matsumura, Y. A Proteasome Inhibitor Prevents Vascular Hypertrophy in Deoxycorticosterone Acetate-Salt Hypertensive Rats. Clin. Exp. Pharmacol. Physiol. 2001, 28, 466-468. [CrossRef]

185. $\mathrm{Wu}, \mathrm{J}$. On the role of proteasomes in cell biology and proteasome inhibition as a novel frontier in the development of immunosuppressants. Am. J. Transplant. 2002, 2, 904-912. [CrossRef] [PubMed]

186. Subklewe, M.; Sebelin-Wulf, K.; Beier, C.; Lietz, A.; Mathas, S.; Dörken, B.; Pezzutto, A. Dendritic Cell Maturation Stage Determines Susceptibility to the Proteasome Inhibitor Bortezomib. Hum. Immunol. 2007, 68, 147-155. [CrossRef] 